\title{
The interaction between arbuscular mycorrhizal fungi and soil phosphorus availability influences plant community productivity and ecosystem stability
}

\author{
Gaowen Yang ${ }^{1}$, Nan Liu', Wenjie Lu ${ }^{1}$, Shuo Wang ${ }^{1}$, Haiming Kan ${ }^{1,2}$, Yingjun Zhang ${ }^{1 *}$, \\ Lan $\mathrm{Xu}^{2}$ and Yongliang $\mathrm{Chen}^{3}$ \\ ${ }^{1}$ Department of Grassland Science, China Agricultural University, Beijing 100193, China; ${ }^{2}$ Department of Natural \\ Resource Management, South Dakota State University, Brookings, SD 57007, USA; and ${ }^{3}$ Research Center for \\ Eco-Environmental Sciences, Chinese Academy of Sciences, Beijing 100085, China
}

\begin{abstract}
Summary
1. Arbuscular mycorrhizal fungi (AMF) can influence plant community composition and diversity. Previous research has shown that the addition of nutrients reduces the effectiveness of AMF. However, the ways in which soil nutrient availability and AMF interact and affect plant community productivity and ecosystem stability are still poorly understood.

2. We examined the impact of AMF suppression and phosphorus $(\mathrm{P})$ addition on plant diversity, community productivity and temporal stability (TS) in a field experiment. AMF root colonization and the concentration of an AMF-specific phospholipid fatty acid were significantly reduced after application of the fungicide benomyl as a soil drench.

3. The TS of the plant community was higher in communities without benomyl application compared with communities with benomyl application indicating that AMF contribute to the TS of plant communities. AMF suppression increased productivity at the plant species, functional group and community levels under high $\mathrm{P}$ addition rates. At the zero $\mathrm{P}$ addition rate, AMF did not affect plant community productivity, as the dominant species Artemisia frigida was more abundant in control plots with AMF, while the subdominant species Stipa krylovii was more abundant in the benomyltreated plots with reduced AMF abundance. Compensatory effects between $\mathrm{C}_{3}$ grasses and non- $\mathrm{N}_{2}$ fixing forbs were observed in the control plots with AMF along the gradient of $\mathrm{P}$ addition rates, but these effects were not detected among plant species in the benomyl-treated plots under AMF suppression above an addition rate of $4.76 \mathrm{P}_{2} \mathrm{O}_{5} \mathrm{~m}^{-2}$ year $^{-1}$. Although AMF suppression did not influence the diversity of the plant communities, it did decrease the diversity of $\mathrm{N}_{2}$-fixing forbs at the zero $\mathrm{P}$ addition rate and above an addition rate of $18.90 \mathrm{~g} \mathrm{P}_{2} \mathrm{O}_{5} \mathrm{~m}^{-2}$ year ${ }^{-1}$, indicating that AMF play key roles in the maintenance of $\mathrm{N}_{2}$-fixing forbs at these $\mathrm{P}$ addition rates. $\mathrm{P}$ addition led to biodiversity losses at application rates below $2.36 \mathrm{~g} \mathrm{P}_{2} \mathrm{O}_{5} \mathrm{~m}^{-2}$ year ${ }^{-1}$ at the community level.

4. Synthesis. Arbuscular mycorrhizal fungi and soil $\mathrm{P}$ availability interact to influence the productivity and TS of a plant community by mediating compensatory effects among plant species and functional groups.
\end{abstract}

Key-words: antagonism, benomyl, compensatory effects, legume, mutualism, phosphorus fertilization, plant-soil (below-ground) interactions, symbiosis, temporal stability

\section{Introduction}

Identifying the factors that maintain plant diversity, productivity and ecosystem stability are a key issue in ecology. Soil microbes, such as arbuscular mycorrhizal fungi (AMF), are important components of ecosystems and play critical roles in

*Correspondence author. E-mail: zhangyj@cau.edu.cn above-ground productivity and the maintenance of plant diversity (van der Heijden et al. 1998; Hartnett \& Wilson 1999; O'Connor, Smith \& Smith 2002; Collins \& Foster 2009). AMF are often considered classical mutualists that promote plant growth (van der Heijden et al. 1998, 2006). AMF provide soil resources for plants and receive photosynthates in return (Johnson 2010). Nutrient addition can alter the costs and benefits of AMF-plant symbiosis and induce antagonism 
(Johnson, Graham \& Smith 1997; Grman 2012; Grman \& Robinson 2013). However, the community consequences of plant-mycorrhizal interactions caused by nutrient addition are still poorly understood.

In this context, the relationships between plants and AMF are defined in terms of plant growth responses. Positive plant growth associated with AMF indicates mutualism, while negative plant growth associated with AMF indicates antagonism (Francis \& Read 1995; Johnson 2010; Grman 2012; Johnson \& Graham 2013). The concept of 'parasitism' discussed in some previous studies (Francis \& Read 1995; Johnson 2010; Grman 2012) is equivalent to 'antagonism' in this study. Nutrient addition can induce antagonism when the net cost to a plant exceeds the net benefits from the fungus (Grman 2012; Johnson \& Graham 2013). For example, when phosphorus $(\mathrm{P})$ is scarce, plants often benefit from AMF-plant symbiosis, and AMF increase plant growth (Hoeksema et al. 2010), but when $P$ is abundant, plants may receive little or no benefit from AMF, and AMF may therefore reduce plant growth (Johnson, Graham \& Smith 1997; Johnson 2010).

The influence of $\mathrm{P}$ enrichment on AMF-plant symbiosis along the mutualism-antagonism spectrum varies among plant functional groups (Hoeksema et al. 2010; Grman 2012). $\mathrm{C}_{4}$ grasses and non- $\mathrm{N}_{2}$-fixing forbs often show a more positive response to $A M F$ inoculation than $C_{3}$ grasses and $N_{2}$-fixing forbs (Hoeksema et al. 2010). Grman (2012) reported that $P$ fertilization induced antagonism and that $\mathrm{C}_{4}$ and $\mathrm{C}_{3}$ grasses differed in their growth response to antagonism along the gradient of $\mathrm{P}$ addition rates. The $\mathrm{C}_{4}$ grasses weakly reduced AMF root colonization but did not affect AMF hyphal abundance, whereas the $\mathrm{C}_{3}$ grasses effectively suppressed AMF root colonization and $\mathrm{AMF}$ hyphal abundance, which indicated that $\mathrm{C}_{4}$ grasses suffered more severe antagonism than $\mathrm{C}_{3}$ grasses (Grman 2012). However, the effect of the different mycorrhizal growth responses of the various plant functional groups on plant community productivity is still unknown.

The effect of AMF on plant diversity depends on the mycorrhizal dependence of dominant and subordinate species in a plant community (Hartnett \& Wilson 1999; O'Connor, Smith \& Smith 2002; Urcelay \& Diaz 2003). If subordinate species are highly mycorrhizal dependent, the presence of AMF should increase plant diversity, irrespective of the mycorrhizal dependence of the dominant species (Urcelay \& Diaz 2003). In a tall-grass prairie, Hartnett \& Wilson (1999) reported that suppression of AMF in situ resulted in a decrease in the abundance of the dominant species, leading to a compensatory increase in the abundance of the subordinate species, which in turn increased the level of plant diversity. Collins \& Foster (2009) examined the impact of soil P levels and AMF on plant diversity in artificial microcosm communities and found that AMF were important for mediating plant community diversity when $\mathrm{P}$ availability decreased, but AMF had little influence on diversity at high $\mathrm{P}$ levels. Both soil nutrients and the mycorrhizal dependence of the dominant and subordinate species should be considered when attempting to predict the effects of AMF on plant diversity (O’Connor, Smith \& Smith 2002; Collins \& Foster 2009).
AMF have also been shown to influence ecosystem variability in artificial microcosms (van der Heijden et al. 1998). Decrease in AMF diversity could increase ecosystem instability, according to van der Heijden et al. (1998). However, no studies have addressed the interactive effects of AMF-plant symbiosis and nutrient addition on ecosystem stability. Stability has different interpretations in ecology. We used temporal stability (TS) to represent ecosystem stability in this study (Tilman, Reich \& Knops 2006). Interspecific competition is a key factor that stabilizes ecosystem properties through compensatory interactions between plant species (Naeem \& $\mathrm{Li}$ 1997; Bai et al. 2004; Loreau \& de Mazancourt 2013). In our study, compensatory effects are indicated by negative Spearman's correlation coefficients between plant species or functional groups, following Bai et al. (2004). Previous work has shown that the identity and diversity of AMF can mediate plant-plant interactions by relaxing plant-plant competition and altering the coexistence of plants and resource distribution between co-occurring plants (Hart, Reader \& Klironomos 2003; van der Heijden, Wiemken \& Sanders 2003; Wagg et al. 2011). Furthermore, the effects of AMF on plant-plant interactions depend on P availability (Collins \& Foster 2009; Zhou 2013). Thus, AMF might influence ecosystem stability by increasing or reducing compensatory interactions between plant species, and this influence may be mediated by soil $\mathrm{P}$ availability.

Numerous studies have investigated the effects of AMF on plant community structure and diversity in European grasslands (van der Heijden et al. 1998; van der Heijden, Verkade $\&$ de Bruin 2008), Australian semi-arid herblands (O'Connor, Smith \& Smith 2002) and North American prairies (Hartnett \& Wilson 1999; Collins \& Foster 2009). In the current study, we conducted a field experiment in the grasslands of Inner Mongolia, which are part of the Eurasian steppe - the largest contiguous grassland in the world - to test the impact of $\mathrm{P}$ addition and AMF suppression on plant productivity, diversity and TS. Previous studies have generally shown that $\mathrm{P}$ is not a limiting nutrient in the steppe (Liu et al. 2007; Gong et al. 2011). We expected that $P$ addition would induce antagonism on the non-P-limited steppe. Our aim was to address three questions: (i) Can $\mathrm{P}$ addition induce antagonism? (ii) How do AMF affect plant community productivity and diversity under $\mathrm{P}$ addition? (iii) Do AMF affect TS by mediating plant-plant interactions along the gradient of $\mathrm{P}$ addition rates?

\section{Materials and methods}

\section{STUDY SITE}

This experiment was conducted at the Duolun Restoration Ecology Station of the Institute of Botany of the Chinese Academy of Sciences, which is located on the Inner Mongolian steppe $\left(42^{\circ} 02^{\prime} \mathrm{N}\right.$, $116^{\circ} 17^{\prime} \mathrm{E}$ ), China. The long-term mean annual precipitation is approximately $383 \mathrm{~mm}$, with $90 \%$ of the total precipitation falling during the growing season from May to October. The mean annual temperature is $2.1{ }^{\circ} \mathrm{C}$, ranging from $-17.5^{\circ} \mathrm{C}$ in January to $18.9^{\circ} \mathrm{C}$ in July. The soils in the study area are classified as Haplic Calcisols according 
to FAO classification. The vegetation is classified as temperate steppe type, dominated by Stipa krylovii, Artemisia frigida, Agropyron cristatum, Leymus chinensis, Potentilla tanacetifolia, Cleistogenes squarrosa and Carex heterostachya (Yang et al. 2012). More than 60\% of the plant species, including the dominant species, have been identified as arbuscular mycorrhizal plants on the steppe (Bao \& Yan 2004; Tian et al. 2009), and the mycorrhizal plants account for $94.61 \%$ of the above-ground community biomass on average at the study sites (see Table S1 in Supporting Information).

\section{EXPERIMENTAL DESIGN}

The experiment was conducted under a two-factor randomized block design and consisted of combinations of two levels of fungicides (benomyl treatment and the control) and six levels of $\mathrm{P}$ addition $\left(0.00,2.36,4.72,9.45,18.90\right.$ and $37.82 \mathrm{~g} \mathrm{P}_{2} \mathrm{O}_{5} \mathrm{~m}^{-2}$ year $\left.^{-1}\right)$ as well as one treatment with no water, no fungicide and no $\mathrm{P}$ addition. There were 10 blocks in total. In May 2010, the 13 treatments were individually and randomly assigned to one of the $2 \times 2 \mathrm{~m}$ plots in each block. Each plot was separated from the others by a 2-m gap and was divided into a central zone of $1.6 \mathrm{~m}$ and a buffer zone of $20 \mathrm{~cm}$ to minimize edge effects. The fungicide treatment plots received benomyl as a soil drench $(6 \mathrm{~g}$ of the active ingredient in $10 \mathrm{~L}$ of water $\mathrm{m}^{-2}$ every 2 weeks) following O'Connor, Smith \& Smith (2002). The control (non-benomyl-treated) plots received $10 \mathrm{~L}$ of water $\mathrm{m}^{-2}$ every 2 weeks. The fungicide treatment and control plots were treated in this manner from 15 May to 1 September of each year. P was added as superphosphate in three equal applications every year, with one application during the early growing season (15 May) and two applications during the middle of the growing season (15 June and 15 July). The study area was fenced to exclude any grassland management and use practices. This experiment was conducted from 2010 to 2012.

We chose the fungicide benomyl for AMF suppression because it has been shown to be effective in reducing AMF colonization, and it has the fewest side effects in the field (Fitter \& Nichols 1988; Hartnett \& Wilson 1999; O'Connor, Smith \& Smith 2002). The phytotoxic and fungitoxic effects of benomyl on non-target fungi have been shown to result in negligible effects on plant growth responses (O'Connor, Smith \& Smith 2002). Moreover, a previous study on the Inner Mongolia steppe indicated that the effects of benomyl addition on plant growth in situ can be attributed to AMF suppression (Shi 2010).

\section{SOIL SAMPLING}

In mid-August of each year, three cylindrical soil cores (10-cm depth and 6-cm diameter) were collected from each plot and mixed in situ into one composite sample. The soil samples (approximately $200 \mathrm{~g}$ ) were air-dried after removing roots and stones by sieving the samples through a 2-mm mesh. To assess the effects of benomyl and P addition on soil microbes, the fresh soil samples (approximately $100 \mathrm{~g}$ ) were frozen and stored at $-80{ }^{\circ} \mathrm{C}$ for phospholipid fatty acid (PLFA) analysis in 2012. The roots were extracted from the root and stone mixtures by washing and were cut into approximately $1-\mathrm{cm}$ segments to estimate $\mathrm{AMF}$ root colonization.

\section{VEGETATION SAMPLING}

One permanent quadrat $(1 \times 1 \mathrm{~m})$ was established in each plot to estimate species richness at the peak of plant biomass production in the middle of August. In late August, one subplot $(0.5 \times 1 \mathrm{~m})$ within each plot was destructively sampled to determine the above-ground biomass of the individual plant species and the community every year. Shoots were cut at the soil surface, sorted by species and ovendried at $65{ }^{\circ} \mathrm{C}$ for $72 \mathrm{~h}$, before being weighed. The shoot dry weight of each species was recorded separately and expressed as the aboveground biomass per $\mathrm{m}^{2}$. Because plant functional groups have been found to be more important in predicting plant mycorrhizal growth responses than other factors (Hoeksema et al. 2010), the plant species were categorized into four functional groups: $\mathrm{C}_{4}$ grasses, $\mathrm{C}_{3}$ grasses, $\mathrm{N}_{2}$-fixing forbs and non- $\mathrm{N}_{2}$-fixing forbs (Table S1).

\section{LABORATORY ANALYSIS}

We analysed $\mathrm{N}$ and $\mathrm{P}$ concentrations in the shoot of A. frigida (non$\mathrm{N}_{2}$-fixing forbs) and $S$. krylovii $\left(\mathrm{C}_{3}\right.$ grasses), which appeared in every plot and produced sufficient shoot biomass to allow determination of both $\mathrm{P}$ and $\mathrm{N}$ concentrations. The shoot $\mathrm{N}$ concentration was measured using a FOSS Kjeltec 2300 Analyser Unit (FOSS, Hillerød, Sweden). The shoot $\mathrm{P}$ concentration was determined using a spectrophotometer, with ammonium molybdate and ascorbic acid as colour reagents (Carter \& Gregorich 2008), following digestion of the plant tissue with nitric and perchloric acids.

The concentrations of inorganic $\mathrm{N}\left(\mathrm{NH}_{4}^{+}-\mathrm{N}\right.$ and $\left.\mathrm{NO}_{3}^{-}-\mathrm{N}\right)$ in the soil were analysed with a flow injection autoanalyser (AutoAnalyser 3; Seal Analytical, Norderstedt, Germany). Soil inorganic N is presented in $\mathrm{mg} \mathrm{kg}^{-1}$. The soil available $\mathrm{P}$ was analysed using the Olsen methods (Carter \& Gregorich 2008). PLFAs were determined according to modified Bligh and Dyer methodology (Frostegård, Tunlid \& Bååth 1991). Qualitative and quantitative PLFA analyses were performed using an Agilent 6890 gas chromatograph (Agilent Technologies, Palo Alto, CA, USA) and SHERLOCK software (MIDI Inc., Newark, NJ, USA). The fatty acids i14:0, i15:0, a15:0, 15:0, i16:0, 16:167c, i17:0, a17:0, 17:0cy, 17:0, 18:1 $\omega 7 \mathrm{c}$ and $18: 1 \omega 5 \mathrm{c}$ were chosen to represent bacterial PLFAs. $16: 1 \omega 5 \mathrm{c}$ was selected to represent the AMF PLFAs, and $18: 2 \omega 6.9 \mathrm{c}$ and $18: 1 \omega 9 \mathrm{c}$ were taken to represent the PLFAs of other fungi (Schnoor, Martensson \& Olsson 2011). The PLFA concentrations from AMF can be used as an indicator of their biomass in the soil (Schnoor, Martensson \& Olsson 2011).

The mixed root samples were taken to the laboratory, cleared in $10 \%(\mathrm{w} / \mathrm{v}) \mathrm{KOH}$ at $90{ }^{\circ} \mathrm{C}$ in a water bath for $120 \mathrm{~min}$, and then washed and stained with $0.05 \%$ (w/v) Trypan blue. Thirty root segments from each sample were mounted on slides in a polyvinyl alcohol-lactic acid-glycerol solution and examined microscopically to assess the percentage of the root length colonized by AMF (Trouvelot, Kough \& Gianinazzi-Pearson 1986).

\section{DATA ANALYSES}

The additional control treatment without water, fungicide and $\mathrm{P}$ addition was removed from all analyses, as it showed no significant difference from the watered, no fungicide, no $\mathrm{P}$ addition treatment with respect to AMF root colonization, species richness and relative proportion of biomass per species. Repeated-measures ANOvAs were performed to test the effects of benomyl application, $\mathrm{P}$ addition and the year as well as their interactions on AMF suppression, above-ground biomass, the plant species present and soil properties. Additional ANOVAS with two fixed factors (benomyl application and P) and one random factor (blocks) were performed to determine the magnitude of the response for each year. Temporal stability was defined as $\mu / \sigma$, where $\mu$ is the mean above-ground community biomass for 2010 , 
2011 and 2012, and $\sigma$ is the standard deviation of the above-ground biomass over the 3 years, according to Tilman, Reich and Knops (2006). To ensure normality, the TS values were log-transformed prior to analysis. A two-way ANOva was applied to examine the effects of AMF suppression and $\mathrm{P}$ addition and their interactions on TS and PLFA concentrations. These ANOvAs were followed by a Tukey's simultaneous test to detect differences between the control and the benomyl treatment. Duncan's multiple range test was also used to compare the effects of each rate of $\mathrm{P}$ addition.

Spearman's correlation was used to analyse the possible correlations between plant species and plant functional groups in terms of their above-ground biomass over time in each treatment (Bai et al. 2004). A significant $(P<0.05)$ negative correlation suggests the potential for compensatory effects, and a positive correlation indicates complementary effects (Bai et al. 2004). Regression models employing soil available $\mathrm{P}$ as a continuous variable were used to determine the relationship between soil $\mathrm{P}$ availability and shoot $\mathrm{N}$ and $\mathrm{P}$ concentrations. All statistical analyses were performed using SAS version 9.1 (SAS Institute, Cary, NC, USA, 2002).

\section{Results}

\section{AMF SUPPRESSION}

Benomyl application significantly decreased AMF root colonization across all $\mathrm{P}$ addition rates (Fig. 1a; $F_{1,99}=20.53$, $P<0.001)$. AMF root colonization decreased with $\mathrm{P}$ addition (Fig. $1 \mathrm{a} ; F_{5,99}=10.28, P<0.001$ ). The AMF PLFA concentrations did not respond significantly to $\mathrm{P}$ addition (Fig. 1b; $F_{5,99}=0.64, P>0.05$ ), but it did decrease under the benomyl treatment (Fig. 1b; $F_{1,99}=26.16, P<0.001$ ).

The concentrations of the other fungal and bacterial PLFAs were not significantly influenced by the benomyl treatment $\left(F_{1,99}=1.09, P>0.05 ; F_{1,99}=3.74, P>0.05\right.$, respectively $)$ or $\mathrm{P}$ addition $\left(F_{5,99}=0.34, P>0.05 ; F_{5,99}=0.79, P>0.05\right.$, respectively), and no signs of pathogenic fungi or their effects were observed through visual inspection of the roots. Furthermore, $\mathrm{P}$ addition significantly increased soil available $\mathrm{P}$ (Fig. S1a; $F_{5,99}=1060.80, P<0.001$ ). Soil inorganic $\mathrm{N}$ was not significantly affected by the benomyl treatment or $\mathrm{P}$ addition (Fig. S1b; $F_{1,99}=1.45, \quad P>0.05 ; \quad F_{5,99}=1.40$, $P>0.05$, respectively).

\section{ABOVE-GROUND BIOMASS OF COMMUNITY AND FUNCTIONAL GROUPS}

The above-ground community biomass did not show a significant response to $\mathrm{P}$ addition in the control treatment in 2010, 2011 or 2012 (Fig. 2a,b and c; all $P>0.05$ ), but it did increase under $\mathrm{P}$ addition in the benomyl treatment (Fig. 2a,b and $\mathrm{c} ; \quad F_{5,54}=3.18, \quad P<0.05 ; \quad F_{5,54}=4.02, \quad P<0.01$; $F_{5,54}=3.84, P<0.01$, respectively). No significant difference was detected in the above-ground community biomass between the control and the benomyl treatment at the zero $\mathrm{P}$ addition rate from 2010 to 2012 (Fig. 2a-c; all $P>0.05$ ). However, the benomyl treatment significantly increased the above-ground community biomass above an addition rate of $2.36 \mathrm{~g} \mathrm{P} \mathrm{P}_{2} \mathrm{O}_{5} \mathrm{~m}^{-2}$ in 2011 and 2012 (Fig. 2b,c; Tukey's
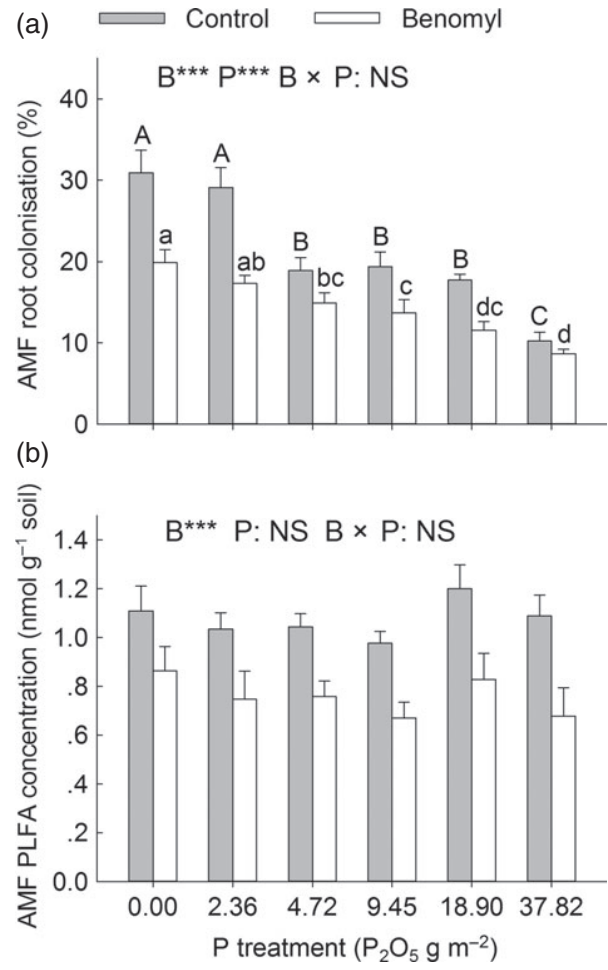

Fig. 1. Effects of benomyl application (B) and $\mathrm{P}$ addition $(\mathrm{P})$ on the arbuscular mycorrhizal fungi root colonization of mixed roots (a) and the concentration of mycorrhizal phospholipid fatty acid $(16: 1 \omega 5 \mathrm{c})$ in the soil (b). Bar groups with different capital letters indicate significant differences $(P<0.05)$ between the six $\mathrm{P}$ addition rates under the control treatment. Bar groups with different lowercase letters indicate significant differences $(P<0.05)$ between the six $\mathrm{P}$ addition rates under the benomyl treatment. Data are means \pm SE. $* P<0.05$; $* * P<0.01 ; * * * P<0.001$; NS $P>0.05$.

simultaneous test, $P<0.05$ ). There was a significant positive interaction between the control treatment and $\mathrm{P}$ addition found for TS (Fig. 2d; benomyl treatment $\times \mathrm{P}$ addition: $\left.F_{5,99}=2.8, P<0.05\right)$. TS showed a significant reduction under the benomyl treatment relative to the control above an addition rate of $4.76 \mathrm{P}_{2} \mathrm{O}_{5} \mathrm{~m}^{-2}$ (Fig. 2d; Tukey's simultaneous test, $P<0.05$ ).

The above-ground biomass of non- $\mathrm{N}_{2}$-fixing forbs was decreased by the benomyl treatment at the zero $\mathrm{P}$ addition rate from 2010 to 2012 (Fig. 3a,e,i; Tukey's simultaneous test, $P<0.05)$. However, the biomass of non- $\mathrm{N}_{2}$-fixing forbs increased by $26-57 \%$ in the benomyl treatment compared with the control at $\mathrm{P}$ addition rates above $2.36 \mathrm{~g} \mathrm{P}_{2} \mathrm{O}_{5} \mathrm{~m}^{-2}$ from 2010 to 2012 (Fig. 3a,e,i; benomyl treatment $\times \mathrm{P}$ addition: $F_{5,99}=2.54, P<0.05 ; F_{5,99}=2.70, P<0.05 ; F_{5,99}=3.10$, $P<0.05$, respectively). The benomyl treatment tended to increase the above-ground biomass of $\mathrm{C}_{3}$ grasses in 2011 and 2012 and did not significantly affect it in 2010 (Fig. 3b,f,j). The above-ground biomass of $\mathrm{C}_{4}$ grasses did not respond significantly to $\mathrm{P}$ addition or benomyl treatment in 2011 and 2012 (all $P>0.05$ ), whereas increased with $\mathrm{P}$ addition in 2012 (Fig. 3c,g,k). The above-ground biomass of $\mathrm{N}_{2}$-fixing forbs did not respond significantly to $\mathrm{P}$ addition or benomyl treatment in 2011 and 2012, while it decreased under benomyl treatment at 

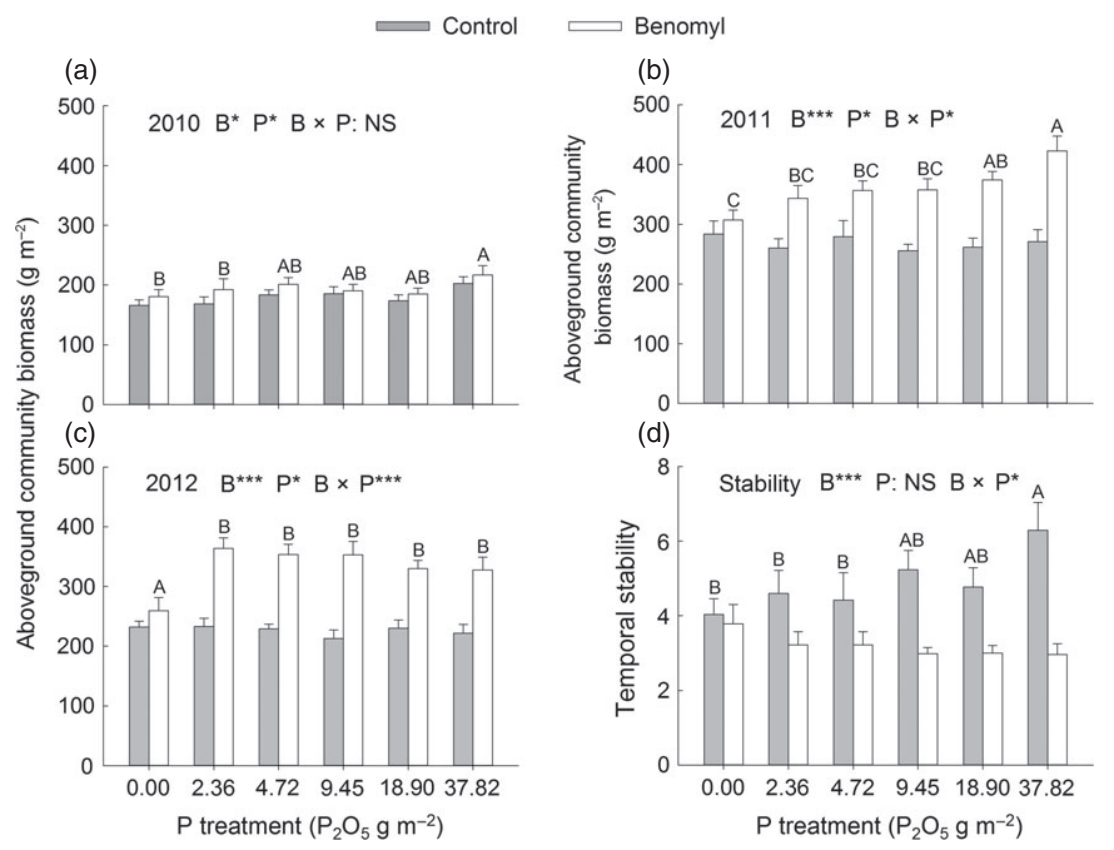

Fig. 2. Effects of benomyl application (B) and $\mathrm{P}$ addition ( $\mathrm{P}$ ) on the above-ground community biomass in 2010 (a), 2011 (b) and 2012 (c) and on temporal stability (d). Bar groups with different capital letters indicate significant difference $(P<0.05)$ between the six $\mathrm{P}$ addition rates under the control or benomyl treatment. Data are means \pm SE. $* P<0.05 ;{ }^{* * *} P<0.001$; NS $P>0.05$.
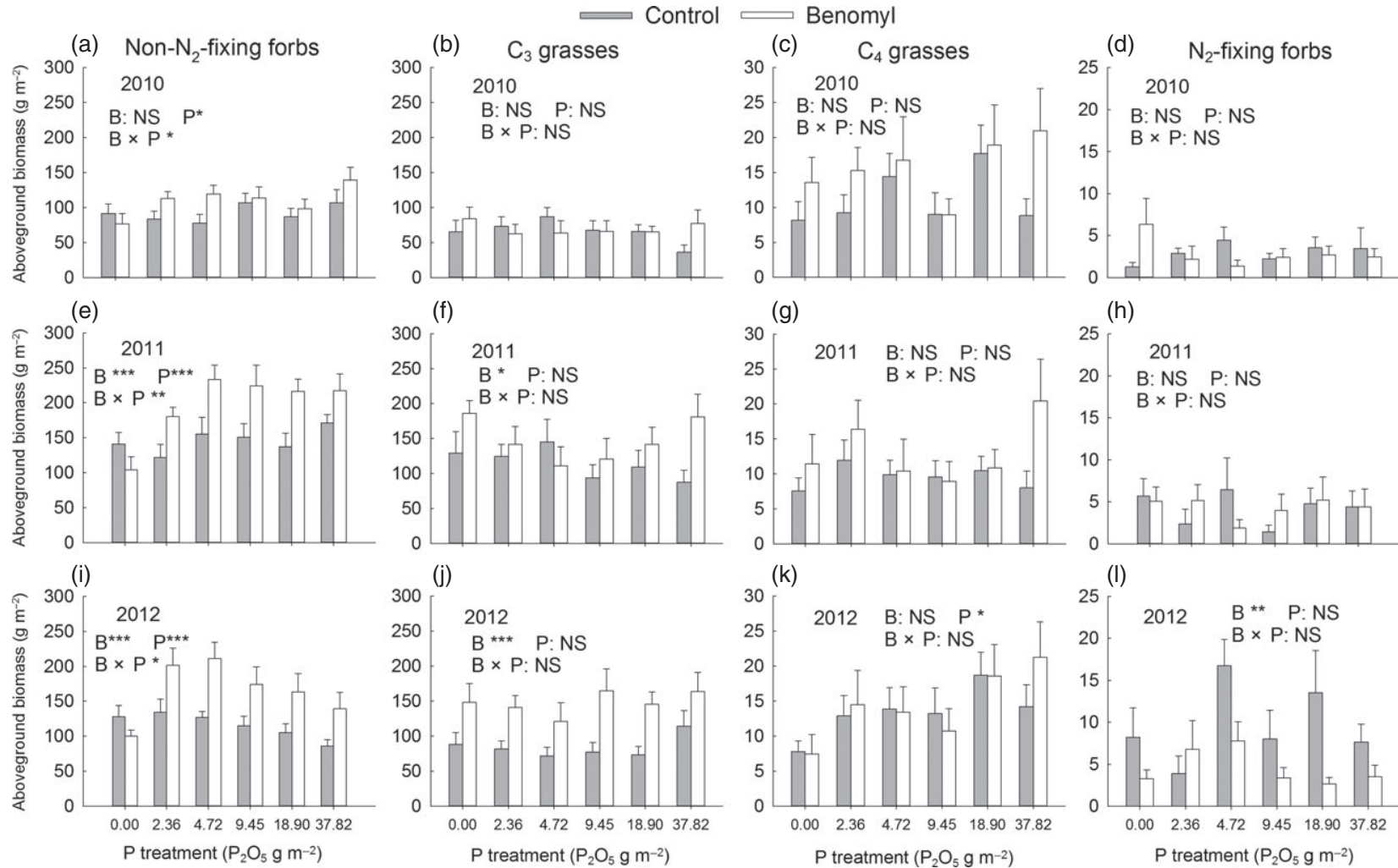

Fig. 3. Effects of benomyl application (B) and $P$ addition $(P)$ on the above-ground biomass of non- $\mathrm{N}_{2}$-fixing forbs (a, e and i), $\mathrm{C}_{3}$ grasses (b, $\mathrm{f}$ and j), $\mathrm{C}_{4}$ grasses (c, g and k) and $\mathrm{N}_{2}$-fixing forbs (d, $\mathrm{h}$ and $\mathrm{l}$ ) from 2010 to 2012. Data are means $\pm \mathrm{SE}$. ${ }^{*} P<0.05 ; * * P<0.01 ;{ }^{* * *} P<0.001$; NS $P>0.05$.

the zero $\mathrm{P}$ addition rate and at high $\mathrm{P}$ addition rates in 2012

(Fig. 3d,h,1; Tukey's simultaneous test, $P<0.05$ ).

\section{ABOVE-GROUND BIOMASS OF INDIVIDUAL SPECIES}

The benomyl treatment significantly increased the aboveground biomass of most species when $\mathrm{P}$ was added, with the exception of C. squarrosa and A. cristatum (Fig. 4). The benomyl treatment increased the above-ground biomass of S. krylovii and A. cristatum at the highest $\mathrm{P}$ addition rates as well as that of $L$. chinensis at intermediate $\mathrm{P}$ addition rates ranging from 4.72 to $18.90 \mathrm{~g} \mathrm{P}_{2} \mathrm{O}_{5} \mathrm{~m}^{-2}$ (Fig. 4a,d,f; Tukey's simultaneous test, $P<0.05)$. Additionally, the above-ground biomass of $A$. frigida and $C$. heterostachya was increased by 

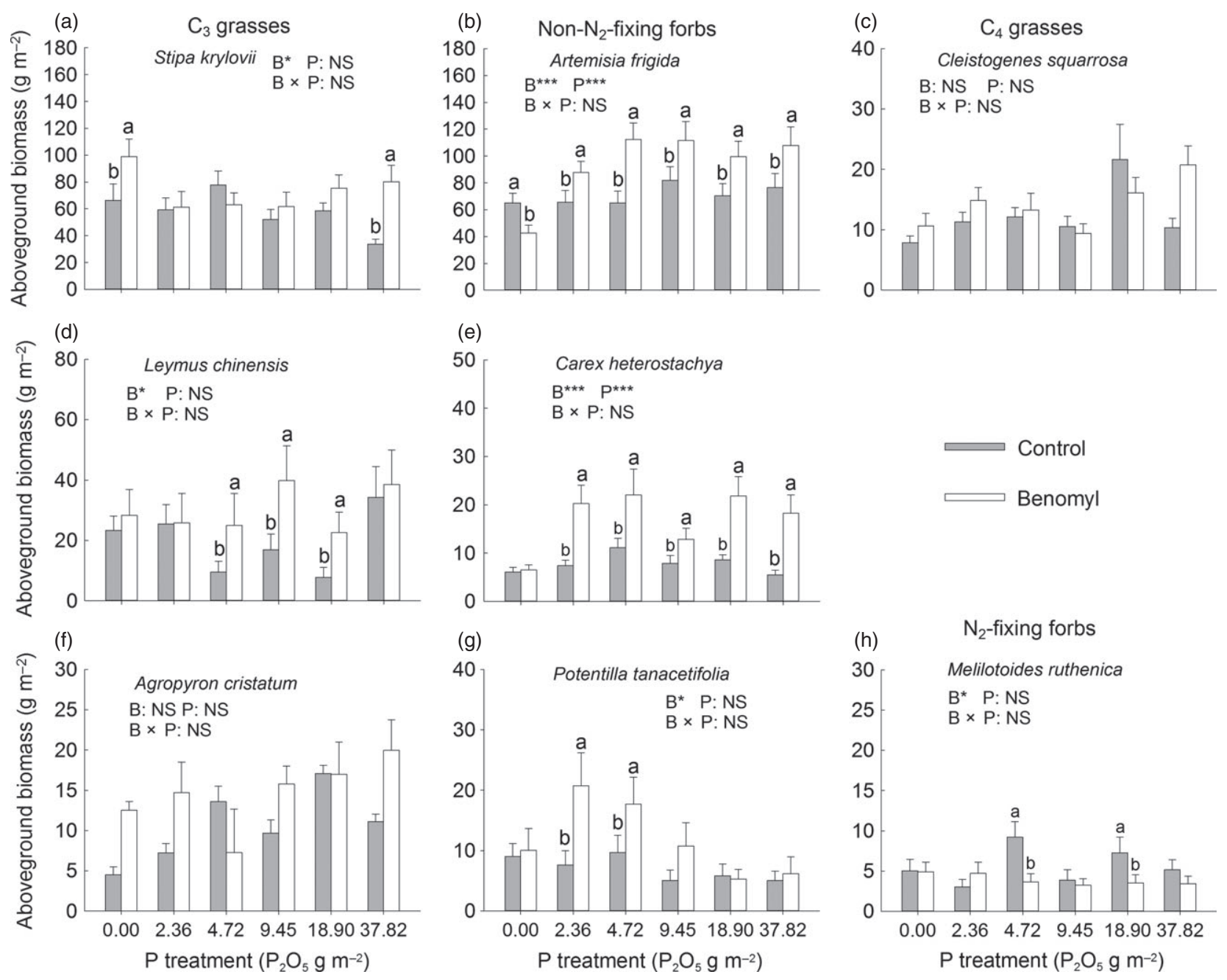

Fig. 4. Above-ground biomass of the main plant species under the benomyl application and P addition treatments averaged from 2010 to 2012. Bar groups with different lowercase letters indicate significant differences $(P<0.05)$ between the control and benomyl treatments. Data are means \pm SE. $* P<0.05 ; * * * P<0.001 ;$ NS $P>0.05$.

benomyl treatment at $\mathrm{P}$ addition rates ranging from 2.36 to $37.82 \mathrm{~g} \mathrm{P}_{2} \mathrm{O}_{5} \mathrm{~m}^{-2}$ (Fig. 4b,e; Tukey's simultaneous test, $P<0.05)$.

The benomyl treatment decreased the above-ground biomass of $A$. frigida, the dominant species, at the zero $\mathrm{P}$ addition rate and that of Melilotoides ruthenica at addition rates of 4.72 and $18.90 \mathrm{~g} \mathrm{P}_{2} \mathrm{O}_{5} \mathrm{~m}^{-2}$ (Fig. 4b,h; Tukey's simultaneous test, $P<0.05)$. The above-ground biomass of $C$. squarrosa and A. cristatum was not affected by the benomyl treatment or $\mathrm{P}$ addition (Fig. 4c; Table S2; all $P>0.05$ ).

\section{CORRELATIONS BETWEEN PLANT SPECIES AND FUNCTIONAL GROUPS}

At the species level, negative correlations were detected for three pairs in the benomyl treatment and 13 pairs in the control (Table S3). Negative correlations were not found under the benomyl treatment, and no negative correlations were observed above an addition rate of $4.76 \mathrm{P}_{2} \mathrm{O}_{5} \mathrm{~m}^{-2}$. Negative correlations were detected between the dominant and subdominant or non-dominant species in the control (Table S3). For instance, A. frigida showed a negative correlation with S. krylovii, C. heterostachya and L. chinensis. However, positive correlations were found for 13 pairs in the benomyl treatment and 17 pairs in the control mainly between subdominant and non-dominant species (Table S3).

A similar trend was found at the level of plant functional group. Significant negative correlations between the dominant and subdominant species were lacking in the benomyl treatment (Table S3). Negative correlations between plant functional groups were detected for 3 pairs in the benomyl treatment and eight pairs in the control (Table 1). Negative correlations were observed between $\mathrm{C}_{3}$ grasses and non- $\mathrm{N}_{2}-$ fixing forbs in the control, across the range of $\mathrm{P}$ addition (Table 1).

\section{SPECIES RICHNESS}

The species richness of the plant community and that of non$\mathrm{N}_{2}$-fixing forbs showed no significant responses to the 
Table 1. Spearman's correlation coefficients between plant functional groups in terms of their above-ground biomass $(n=30)$

\begin{tabular}{|c|c|c|c|c|c|c|}
\hline \multirow[b]{2}{*}{ Treatment } & \multicolumn{6}{|c|}{ Plant functional groups } \\
\hline & $\mathrm{C}_{4}$ vs. $\mathrm{C}_{3}$ & $\mathrm{C}_{4}$ vs. NF & $\mathrm{C}_{4}$ vs. NNF & $\mathrm{C}_{3}$ vs. NF & $\mathrm{C}_{3}$ vs. NNF & NF vs. NNF \\
\hline B0P1 & -0.0410 & 0.2446 & -0.1262 & 0.2149 & $-0.5484 * *$ & 0.0607 \\
\hline $\mathrm{B} 0 \mathrm{P} 2$ & -0.0692 & -0.2687 & 0.1695 & -0.0364 & $-0.4946 * *$ & -0.2217 \\
\hline B0P3 & -0.1471 & 0.0827 & -0.1542 & -0.1090 & $-0.4033 *$ & -0.0662 \\
\hline B0P4 & $0.4799 * *$ & -0.2704 & $-0.3851 *$ & -0.3298 & $-0.4474 *$ & 0.0710 \\
\hline B0P5 & -0.0336 & 0.1503 & -0.3406 & -0.1892 & $-0.3873 *$ & $0.4069^{*}$ \\
\hline B0P6 & 0.2013 & 0.1887 & $-0.5146 * *$ & 0.1061 & $-0.6062 * * *$ & 0.0103 \\
\hline B1P1 & -0.2280 & -0.0914 & -0.1048 & -0.0782 & -0.2552 & 0.1961 \\
\hline $\mathrm{B} 1 \mathrm{P} 2$ & -0.1591 & -0.0123 & 0.1244 & 0.3228 & 0.1404 & 0.1460 \\
\hline $\mathrm{B} 1 \mathrm{P} 3$ & -0.0138 & 0.0433 & -0.0823 & -0.1446 & -0.1813 & 0.2214 \\
\hline B1P4 & 0.3606 & 0.0283 & -0.2614 & 0.0621 & $-0.4140 *$ & 0.0450 \\
\hline B1P5 & $-0.3709 *$ & $-0.3862 *$ & -0.0091 & 0.1640 & -0.0327 & -0.0372 \\
\hline B1P6 & -0.2476 & -0.0508 & 0.0732 & 0.3872* & -0.2948 & 0.0200 \\
\hline
\end{tabular}

$\mathrm{C}_{4}, \mathrm{C}_{4}$ grasses; $\mathrm{C}_{3}, \mathrm{C}_{3}$ grasses; $\mathrm{NF}, \mathrm{N}_{2}$-fixing forbs; NNF, non- $\mathrm{N}_{2}$-fixing forbs; $\mathrm{B} 0$, no benomyl treatment; $\mathrm{B} 1$, benomyl treatment; P1-P6: six levels of $\mathrm{P}$ addition, ranging from 0.00 to $37.82 \mathrm{~g} \mathrm{P}_{2} \mathrm{O}_{5} \mathrm{~m}^{-2}$ year $^{-1}$.

Significant correlations are indicated in bold.

${ }^{*} P<0.05 ;{ }^{* *} P<0.01 ; * * * P<0.001$

benomyl treatment (Fig. 5a,b; Table S4; all $P>0.05$ ). However, the species richness of the plant community declined at $\mathrm{P}$ addition rates above $2.36 \mathrm{~g}_{2} \mathrm{O}_{5} \mathrm{~m}^{-2}$ compared with the zero $\mathrm{P}$ addition rate (Fig. 5a; $F_{5,99}=45.33, P<0.05$ ). $\mathrm{P}$ addition also decreased the species richness of non- $\mathrm{N}_{2}$-fixing forbs (Fig. $5 \mathrm{~b} ; F_{5,99}=2.53, P<0.05$ ). The species richness of $\mathrm{N}_{2}$-fixing forbs did not alter with $\mathrm{P}$ addition (Fig. 4c; Table S4; $P>0.05$ ), while it tended to decrease under the benomyl treatment (Fig. $4 \mathrm{c} ; F_{1,99}=5.14, P<0.05$ ). $\mathrm{C}_{4}$ and $\mathrm{C}_{3}$ grasses did not show a significant response to either $\mathrm{P}$ addition or the benomyl treatment (Table S4; all $P>0.05$ ).

\section{SHOOT N AND P CONCENTRATIONS ASSOCIATED WITH SOIL P AVAILABILITY}

The shoot $\mathrm{P}$ concentration in A. frigida increased with the level of soil available $\mathrm{P}$ in the control treatment (Fig. 6a), whereas it increased only at low levels of soil available $\mathrm{P}$ in the benomyl treatment (Fig. 6a). The benomyl treatment decreased the shoot $\mathrm{P}$ concentrations in A. frigida and S. krylovii (Fig. 6a,b), whereas the shoot $\mathrm{P}$ concentration in $S$. krylovii showed a positive linear relationship with soil available $\mathrm{P}$ in both the control and benomyl treatments (Fig. 6b). The shoot $\mathrm{N}$ concentrations in A. frigida and $S$. krylovii exhibited slightly negative relationships with soil available P (Fig. 6c, d).

$\mathrm{P}$ addition reduced the $\mathrm{N}$ and $\mathrm{P}$ benefits obtained from AMF. The shoot $\mathrm{N}$ and $\mathrm{P}$ contents of A. frigida were increased under the control treatment at the zero $\mathrm{P}$ addition rate but decreased at high $\mathrm{P}$ addition rates (Table S5; Fig. S2a,c; Tukey's simultaneous test, $P<0.05$ ). The shoot $\mathrm{N}$ and $\mathrm{P}$ contents of S. krylovii were decreased under the control treatment at the zero $\mathrm{P}$ addition rate and above an addition rate of $18.92 \mathrm{P}_{2} \mathrm{O}_{5} \mathrm{~m}^{-2}$, whereas they were not affected at intermediate $\mathrm{P}$ addition rates (Table S5; Fig S2b,d; Tukey's simultaneous test, $P<0.05)$.

\section{Discussion}

Benomyl application significantly reduced AMF root colonization and the AMF PLFA concentrations, without significantly altering PLFA concentrations of other soil fungi and bacteria. A previous study conducted in a tall-grass prairie showed that benomyl treatment for 8 years did not alter the total fungal or bacterial biomass or microbial carbon or nitrogen (Hartnett \& Wilson 1999). In the present study, AMF root colonization was reduced by approximately $50 \%$ relative to the control at the zero $\mathrm{P}$ addition rate (Fig. 1a), consistent with results of previous studies in which benomyl was applied to native grasslands (Hartnett \& Wilson 1999; Grogan \& Chapin 2000; O'Connor, Smith \& Smith 2002; Shi 2010). Although the fungicide treatment may suppress pathogenic fungi as well as AMF to enhance productivity (Maron et al. 2011), symptoms associated with pathogenic fungi were not detected through visual inspection of the roots, and the benomyl treatment did not result in a significant increase in the above-ground community biomass at the zero $\mathrm{P}$ addition rate. Thus, we can exclude the potential increase in productivity through suppression of pathogenic fungi. Furthermore, the importance of AMF on plant may be underestimated because the effectiveness of AMF cannot be totally suppressed (Kahiluoto, Ketoja \& Vestberg 2000).

The decrease in the AMF PLFA concentrations associated with the benomyl treatment indicated suppression of AMF function. The AMF PLFA concentrations in soil samples show a positive linear relationship with mycorrhizal hyphal density (Balser, Treseder \& Ekenler 2005). AMF are an integral component of plant ecosystems, in which individual mycorrhizal plants may be linked together in soil hyphal networks (Smith \& Read 2008). The shoot P concentration, which is a main indicator of AMF function, showed a positive linear relationship with hyphal density (van der Heijden, 2004). Therefore, the examination of AMF PLFAs combined 

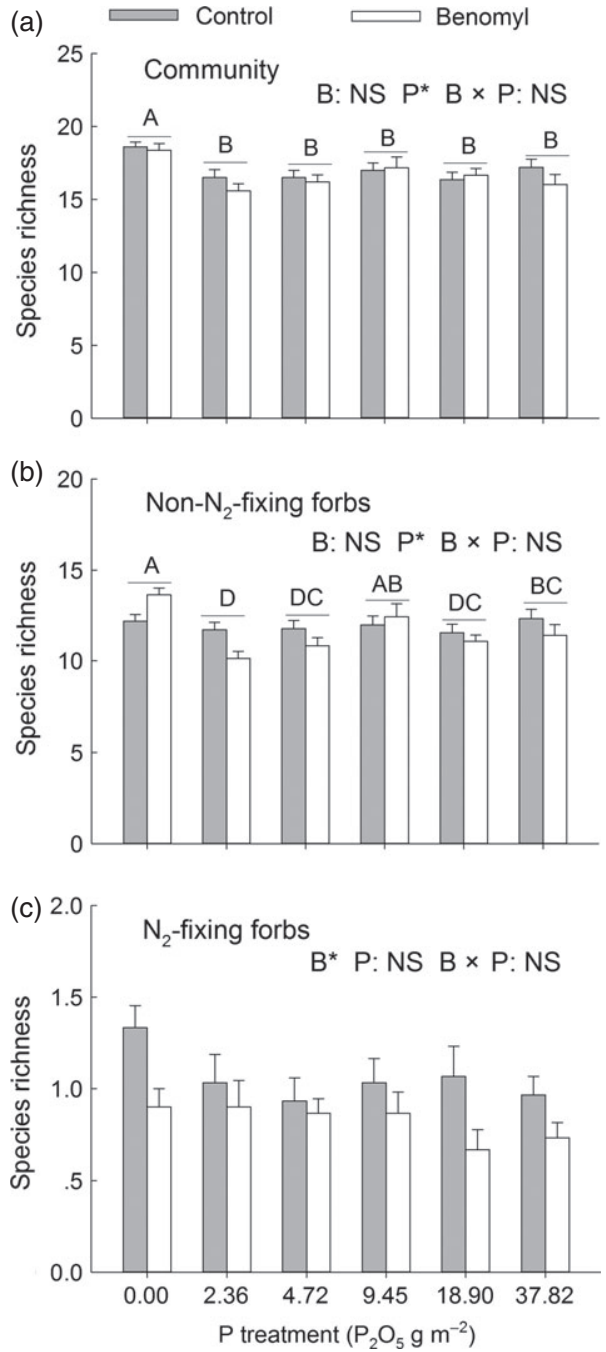

Fig. 5. Species richness of the plant community (a), non- $\mathrm{N}_{2}$-fixing forbs (b) and $\mathrm{N}_{2}$-fixing forbs (c) under the benomyl application and $\mathrm{P}$ addition treatments averaged from 2010 to 2012. Different letters above the bars indicate statistically significant differences between the $\mathrm{P}$ addition rates at $P<0.05$. Data are means \pm SE. $* P<0.05$; NS $P>0.05$.

with root colonization can illustrate that AMF function is suppressed by benomyl application. The reduced shoot $\mathrm{P}$ and $\mathrm{N}$ concentrations associated with the benomyl treatment (Fig. 6) corroborate the suppression of AMF function.

The productivity of above-ground community was not limited by P in the control treatment from 2010 to 2012, consistent with previous findings in steppe ecosystems (Liu et al. 2007; Gong et al. 2011). The above-ground community biomass was not altered by AMF suppression at the zero P addition rate, but it increased when $\mathrm{P}$ was added (Fig. 3), consistent with a field study conducted by Grogan \& Chapin (2000). Collins \& Foster (2009) reported that AMF could decrease plant community productivity at the highest $\mathrm{P}$ addition rate tested in an artificial microcosm community. The different growth responses of plant functional groups to $\mathrm{P}$ addition and benomyl application can explain the changes in plant community biomass. The biomass of $\mathrm{C}_{3}$ grasses was increased by benomyl application in the present study, whereas the biomass of non- $\mathrm{N}_{2}$-fixing forbs was decreased at the zero $\mathrm{P}$ addition rate. As a result, benomyl application had no effect on the above-ground community biomass when no nutrients were added, consistent with previous field studies (West, Fitter \& Watkinson 1993; Newsham, Fitter \& Watkinson 1994; Hartnett \& Wilson 1999; Grogan \& Chapin 2000; O'Connor, Smith \& Smith 2002). $\mathrm{C}_{3}$ grasses and non- $\mathrm{N}_{2}$-fixing forbs were more productive in the benomyl treatment than the control under application rates above $2.36 \mathrm{~g} \mathrm{P}_{2} \mathrm{O}_{5} \mathrm{~m}^{-2}$ (Fig. 3), which led to increase in community productivity. Our results, which are consistent with previous studies (Grogan \& Chapin 2000; Collins \& Foster 2009), suggest that the influence of AMF on plant community productivity depends on soil $\mathrm{P}$ availability.

Arbuscular mycorrhizal fungi can act as mutualists with the dominant species A. frigida and the subdominant species S. krylovii at the zero $\mathrm{P}$ addition rate (Zhen 2012; Zhou 2013). However, AMF did not appear to influence plant community productivity as mutualists based on the compensatory effect between the dominant and subdominant species at the zero $\mathrm{P}$ addition rate in the present study (Table S3; Fig. 4a, b). Our results show that suppression of AMF function increased productivity at the plant species, functional group and community levels under high $\mathrm{P}$ addition rates. These results indicate that $\mathrm{P}$ addition might induce antagonism. The changes in productivity for particular plant species in response to the treatments could be due to competitive or complementary effects among plant species (Wagg et al. 2011), as opposed to simply mutualism or antagonism between plant and AMF, in a mixed-species community. Therefore, antagonism induced by $\mathrm{P}$ addition could not be tested directly in our study.

However, there is evidence that may indirectly support the notion that $\mathrm{P}$ addition induces antagonism. First, previous studies (Zhen 2012; Zhou 2013) have shown that P addition can induce antagonistic effects of AMF on A. frigida and S. krylovii in single-species inoculation experiments. Secondly, such antagonism can be explained by cost-benefit models (Fitter 1991; Johnson 2010). The delicate balance between the benefits gained from AMF in terms of nutrient acquisition and the costs supported by plants can be destroyed by P addition (Johnson, Graham \& Smith 1997; Grman 2012; Grman \& Robinson 2013). The unaltered AMF PLFA concentrations were interpreted as indicating an unaltered biomass in the soil, which is an indicator of plant carbon allocation to AMF (Fitter 1986, 1991; Johnson 2010; Schnoor, Martensson \& Olsson 2011; Grman 2012). The reductions in shoot $\mathrm{N}$ or $\mathrm{P}$ contents gained from AMF (Fig. S2) have typically been interpreted as a result of a decrease in the nutritional benefits to plants obtained from AMF. Consequently, plants receive fewer nutritional benefits from AMF, without altering the allocation of carbon to AMF along the gradient of $\mathrm{P}$ addition rates, thus inducing antagonism.

The present study showed that benomyl restricted the ability of plants to take up $\mathrm{P}$ (Fig. 6). The $\mathrm{P}$ concentrations in plant tissues are reduced by benomyl only under natural conditions when AMF act as mutualists (Fitter \& Nichols 

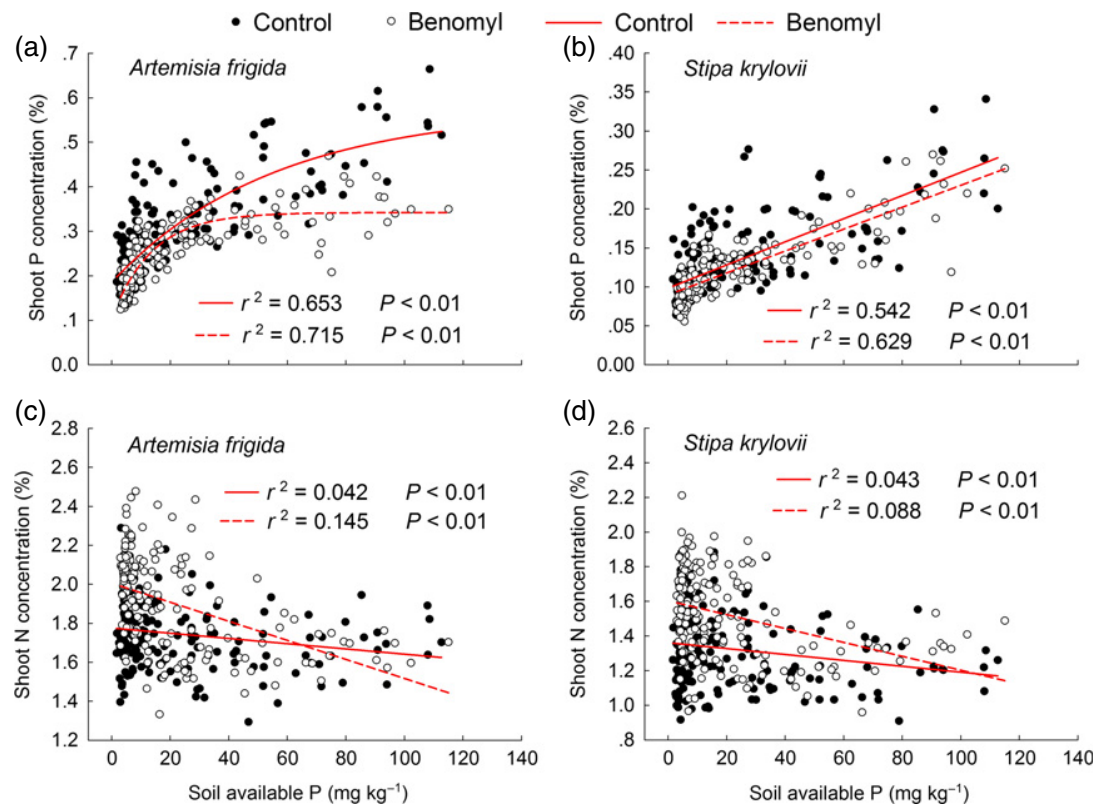

Fig. 6. Relationships between soil available $\mathrm{P}$
and shoot $\mathrm{N}$ or $\mathrm{P}$ concentrations under the
control (solid symbols) and benomyl treatments
(open symbols). Nonlinear relationship: (a)
shoot $\mathrm{P}$ concentration in Artemisia frigida,
solid line $y=0.185+0.389 \times\left(1-e^{-0.018 x}\right.$ )
for the control, short dashed line $y=0.105$
$+0.237 \times\left(1-e^{-0.073 x}\right.$ ) for the benomyl
treatment. Linear relationship: (b) shoot $\mathrm{P}$
concentration in Stipa krylovii; (c) shoot $\mathrm{N}$
concentration in A. frigida; (d) shoot $\mathrm{N}$
concentration in S. krylovii.

1988; Grogan \& Chapin 2000). Stipa krylovii and A. frigida showed luxury $\mathrm{P}$ accumulation in the control, as the shoot $\mathrm{P}$ concentration increased with $\mathrm{P}$ addition, while the biomass did not. Furthermore, the shoot $\mathrm{P}$ concentrations in S. krylovii and A. frigida were lower in the benomyl treatment than in the control across all tested soil available P levels. These results illustrate that AMF contribute to the luxury uptake of $\mathrm{P}$ by plants. Previous studies have suggested that AMF continue to function as effective nutrient-absorbing microbes when plants accumulate P in luxury amounts (Smith \& Read 2008). Our study is one of the few field experiments to yield results consistent with mycorrhizal assistance of the luxury uptake of $\mathrm{P}$ by plants.

Arbuscular mycorrhizal fungi diversity is a determinant of variations in plant community productivity in artificial microcosms (van der Heijden et al. 1998). The present study showed that AMF and $\mathrm{P}$ addition increased TS in an interactive manner above addition rates of $4.72 \mathrm{~g} \mathrm{P}_{2} \mathrm{O}_{5} \mathrm{~m}^{-2}$ (Fig. 2d). Numerous studies have suggested that compensatory effects among plant species and functional groups can be a major driver of TS (Tilman, Reich \& Knops 2006; Yang et al. 2012; Loreau \& de Mazancourt 2013). Negative correlations among plant species and functional groups suggest that compensatory effects may occur and, thus, increase TS, according to Bai et al. (2004). The present work suggested that AMF increased the compensatory effects among plant species and functional groups, as more negative correlations were found in the control compared with the benomyl treatment. Positive correlations potentially indicating the existence of complementary effects can decrease TS (Bai et al. 2004). Positive correlations were found for 13 pairs, and no negative correlations were observed in the benomyl treatment at high $\mathrm{P}$ addition rates (Table S3). Thus, the TS was lower in the benomyl treatment relative to the control at high $\mathrm{P}$ addition rates. Although there is no evidence that AMF have a significant effect on TS in the natural steppe system at a zero $\mathrm{P}$ addition rate, our results demonstrate that AMF show the potential to influence TS under $\mathrm{P}$ addition.

Species richness was not significantly affected by AMF suppression or its interaction with $\mathrm{P}$ addition at the community level (Fig. 5a). The effect of AMF on plant diversity can be predicted mainly based on the mycorrhizal dependence of the dominant and subordinate species (Hartnett \& Wilson 1999; O'Connor, Smith \& Smith 2002; Urcelay \& Diaz 2003). The dominant species A. frigida and subordinate species $S$. krylovii showed different growth responses to AMF at each addition rate (Fig. 5), but plant diversity did not respond significantly to AMF. These findings agree with a previous model in which AMF do not influence plant diversity when $\mathrm{P}$ is not limited (Collins \& Foster 2009).

The species richness of the plant community was reduced under $\mathrm{P}$ addition rates below $2.36 \mathrm{~g} \mathrm{P}_{2} \mathrm{O}_{5} \mathrm{~m}^{-2}$ year $^{-1}$ (1.05 g $\mathrm{P} \mathrm{m}^{-2}$ year $^{-1}$ ). However, Bai et al. (2010) reported that the critical threshold for $\mathrm{N}$-induced species loss was below $1.75 \mathrm{~g} \mathrm{~N} \mathrm{~m}^{-2}$ year $^{-1}$. These results indicate that species richness is more sensitive to $\mathrm{P}$ than to $\mathrm{N}$ addition on the temperate Eurasian steppe. $\mathrm{N}$ addition reduces the species richness of forbs (Bai et al. 2010; Song et al. 2011). Our results show that the species richness of non- $\mathrm{N}_{2}$-fixing forbs could also be reduced by $\mathrm{P}$ addition. Plant biodiversity loss might be attributed to competition for light after anthropogenic eutrophication (Hautier, Niklaus \& Hector 2009). AMF increased the species richness of $\mathrm{N}_{2}$-fixing forbs at the zero $\mathrm{P}$ addition rate (Fig. 5c). In line with this, previous studies have shown that legumes are dependent on mycorrhizal symbiosis if they were to be successful at high $\mathrm{N}$ addition rates (van der Heijden et al. 2006; van der Heijden, Verkade \& de Bruin 2008).

\section{Conclusions}

Our results highlight the potential of AMF to influence community productivity, TS and the species richness of $\mathrm{N}_{2}$-fixing 
forbs associated with $\mathrm{P}$ addition. Although suppression of AMF function increased productivity at the plant species, functional group and community levels under high $\mathrm{P}$ addition rates, the assumption that $\mathrm{P}$ addition induces antagonism could not be tested directly. AMF are less likely to alter the plant diversity of communities that are not limited by $\mathrm{P}$ (Collins \& Foster 2009; Johnson 2010). Our results corroborate previous findings that $\mathrm{AMF}$ continue to function as effective nutrient-absorbing microbes when the plants accumulate $\mathrm{P}$ in luxury amounts (Smith \& Read 2008). Our results also show that species richness is more sensitive to $\mathrm{P}$ than to $\mathrm{N}$ addition and suggests that $\mathrm{P}$ fertilization cannot be used as a management practice to conserve plant diversity.

\section{Acknowledgements}

We are grateful to Junling Zhang, Hanshu Zhou, Chao Jiang and Shujuan Chang for their assistance in the experimental design and to David Kemp, David Hannaway, Marshall Haferkamp, Peter Thrall, Warwick Badgery, Arianne Cease and Haijun Yang for many helpful comments on previous versions of this paper. This study was supported by the earmarked fund for the Major State Basic Research Development Program of China (2014CB138800), the National Natural Science Foundation of China (31270375) and the Modern Agro-industry Technology Research System (CARS-35).

\section{References}

Bai, Y.F., Han, X.G., Wu, J.G., Chen, Z.Z. \& Li, L.H. (2004) Ecosystem stability and compensatory effects in the Inner Mongolia grassland. Nature, 431, 181-184.

Bai, Y.F., Wu, J.G., Clark, C.M., Naeem, S., Pan, Q.M., Huang, J.H., Zhang, L.X. \& Han, X.G. (2010) Tradeoffs and thresholds in the effects of nitrogen addition on biodiversity and ecosystem functioning: evidence from inner Mongolia Grasslands. Global Change Biology, 16, 358-372.

Balser, T.C., Treseder, K.K. \& Ekenler, M. (2005) Using lipid analysis and hyphal length to quantify AM and saprotrophic fungal abundance along a soil chronosequence. Soil Biology and Biochemistry, 37, 601-604.

Bao, Y.Y. \& Yan, W. (2004) Arbuscular mycorrhizae and their structural types on common plants in grasslands of mid-western Inner Mongolia. Biodiversity Science, 12, 501-518.

Carter, M.R. \& Gregorich, E.G. (2008) Soil Sampling and Methods of Analysis, 2nd edn. CRC Press, Boca Raton.

Collins, C.D. \& Foster, B.L. (2009) Community-level consequences of mycorrhizae depend on phosphorus availability. Ecology, 90, 2567-2576.

Fitter, A.H. (1986) Effect of benomyl on leaf phosphorus concentration in alpine grasslands - a test of mycorrhizal benefit. New Phytologist, 103, 767776.

Fitter, A.H. (1991) Costs and benefits of mycorrhizas: implications for functioning under natural conditions. Experientia, 47, 350-355.

Fitter, A.H. \& Nichols, R. (1988) The use of benomyl to control infection by vesicular arbuscular mycorrhizal fungi. New Phytologist, 110, 201-206.

Francis, R. \& Read, D.J. (1995) Mutualism and antagonism in the mycorrhizal symbiosis, with special reference to impacts on plant community structure. Canadian Journal of Botany, 73, 1301-1309.

Frostegård, ̊.., Tunlid, A. \& Bååth, E. (1991) Microbial biomass measured as total lipid phosphate in soils of different organic content. Journal of Microbiological Methods, 14, 151-163.

Gong, X., Chen, Q., Dittert, K., Taube, F. \& Lin, S. (2011) Nitrogen, phosphorus and potassium nutritional status of semiarid steppe grassland in Inner Mongolia. Plant and Soil, 340, 265-278.

Grman, E. (2012) Plant species differ in their ability to reduce allocation to non-beneficial arbuscular mycorrhizal fungi. Ecology, 93, 711-718.

Grman, E. \& Robinson, T.M.P. (2013) Resource availability and imbalance affect plant-mycorrhizal interactions: a field test of three hypotheses. Ecology, 94, 62-71.

Grogan, P. \& Chapin, F.S. (2000) Nitrogen limitation of production in a Californian annual grassland: the contribution of arbuscular mycorrhizae. Biogeochemistry, 49, 37-51.
Hart, M.M., Reader, R.J. \& Klironomos, J.N. (2003) Plant coexistence mediated by arbuscular mycorrhizal fungi. Trends in Ecology \& Evolution, 18, 418-423.

Hartnett, D.C. \& Wilson, G.W.T. (1999) Mycorrhizae influence plant community structure and diversity in tallgrass prairie. Ecology, 80, 1187-1195.

Hautier, Y., Niklaus, P.A. \& Hector, A. (2009) Competition for light causes plant biodiversity loss after eutrophication. Science, 324, 636-638.

van der Heijden, M.G.A. (2004) Arbuscular mycorrhizal fungi as support systems for seedling establishment in grassland. Ecology Letters, 7, 293-303.

van der Heijden, M.G.A., Verkade, S. \& de Bruin, S.J. (2008) Mycorrhizal fungi reduce the negative effects of nitrogen enrichment on plant community structure in dune grassland. Global Change Biology, 14, 2626-2635.

van der Heijden, M.G.A., Wiemken, A. \& Sanders, I.R. (2003) Different arbuscular mycorrhizal fungi alter coexistence and resource distribution between co-occurring plant. New Phytologist, 157, 569-578.

van der Heijden, M.G.A., Klironomos, J.N., Ursic, M., Moutoglis, P., Streitwolf-Engel, R., Boller, T., Wiemken, A. \& Sanders, I.R. (1998) Mycorrhizal fungal diversity determines plant biodiversity, ecosystem variability and productivity. Nature, 396, 69-72.

van der Heijden, M.G.A., Streitwolf-Engel, R., Riedl, R., Siegrist, S., Neudecker, A., Ineichen, K., Boller, T., Wiemken, A. \& Sanders, I.R. (2006) The mycorrhizal contribution to plant productivity, plant nutrition and soil structure in experimental grassland. New Phytologist, 172, 739-752.

Hoeksema, J.D., Chaudhary, V.B., Gehring, C.A., Johnson, N.C., Karst, J., Koide, R.T. et al. (2010) A meta-analysis of context-dependency in plant response to inoculation with mycorrhizal fungi. Ecology Letters, 13, 394 407.

Johnson, N.C. (2010) Resource stoichiometry elucidates the structure and function of arbuscular mycorrhizas across scales. New Phytologist, 185, 631647.

Johnson, N. \& Graham, J. (2013) The continuum concept remains a useful framework for studying mycorrhizal functioning. Plant and Soil, 363, 411-419.

Johnson, N.C., Graham, J.H. \& Smith, F.A. (1997) Functioning of mycorrhizal associations along the mutualism-parasitism continuum. New Phytologist, 135, 575-585.

Kahiluoto, H., Ketoja, E. \& Vestberg, M. (2000) Creation of a non-mycorrhizal control for a bioassay of AM effectiveness 1. Comparison of methods. Mycorrhiza, 9, 241-258.

Liu, M.L., Baoyig, T., Yang, C. \& Zhang, X.S. (2007) Effect of applying N, P, $\mathrm{K}$ to mowing grassland on plant community composition and grassland quality of typical steppe. Journal of Arid Land Resources and Environment, 21, $131-135$.

Loreau, M. \& de Mazancourt, C. (2013) Biodiversity and ecosystem stability: a synthesis of underlying mechanisms. Ecology Letters, 16, 106-115.

Maron, J.L., Marler, M., Klironomos, J.N. \& Cleveland, C.C. (2011) Soil fungal pathogens and the relationship between plant diversity and productivity. Ecology Letters, 14, 36-41.

Naeem, S. \& Li, S. (1997) Biodiversity enhances ecosystem reliability. Nature, 390, 507-509.

Newsham, K.K., Fitter, A.H. \& Watkinson, A.R. (1994) Root pathogenic and arbuscular mycorrhizal fungi determine fecundity of asymptomatic plants in the field. Journal of Ecology, 82, 805-814.

O'Connor, P.J., Smith, S.E. \& Smith, F.A. (2002) Arbuscular mycorrhizas influence plant diversity and community structure in a semiarid herbland. New Phytologist, 154, 209-218.

Schnoor, T.K., Martensson, L.M. \& Olsson, P.A. (2011) Soil disturbance alters plant community composition and decreases mycorrhizal carbon allocation in a sandy grassland. Oecologia, 167, 809-819.

Shi, W.Q. (2010) The effects of arbuscular mycorrhizal fungi on Stipa grandis community in Inner Mongolia grassland. Ecology and Environmental Sciences, 19, 344-349.

Smith, S.E. \& Read, D.J. (2008) Mycorrhizal Symbiosis, 3rd edn. Elsevier, New York, NY

Song, L., Bao, X., Liu, X., Zhang, Y., Christie, P., Fangmeier, A. \& Zhang, F. (2011) Nitrogen enrichment enhances the dominance of grasses over forbs in a temperate steppe ecosystem. Biogeosciences, 8, 2341-2350.

Tian, H., Gai, J., Zhang, J., Christie, P. \& Li, X. (2009) Arbuscular mycorrhizal fungi in degraded typical steppe of inner Mongolia. Land Degradation \& Development, 20, 41-54.

Tilman, D., Reich, P.B. \& Knops, J.M.H. (2006) Biodiversity and ecosystem stability in a decade-long grassland experiment. Nature, 441, 629-632.

Trouvelot, A., Kough, J.L. \& Gianinazzi-Pearson, V. (1986) Mesure dutaux de mycorrhization VA dun systeme radiculaire. Recherche de methodes destimation ayant une signification functionnelle. Physiological and Genetic Aspects 
of Mycorrhizae (eds V. Gianinazzi-Pearson \& S. Gianinazzi), pp. 217-221. INRA, Paris

Urcelay, C. \& Diaz, S. (2003) The mycorrhizal dependence of subordinates determines the effect of arbuscular mycorrhizal fungi on plant diversity. Ecology Letters, 6, 388-391.

Wagg, C., Jansa, J., Stadler, M., Schmid, B. \& van der Heijden, M.G.A. (2011) Mycorrhizal fungal identity and diversity relaxes plant-plant competition. Ecology, 92, 1303-1313.

West, H.M., Fitter, A.H. \& Watkinson, A.R. (1993) The influence of three biocides on the fungal associates of the roots of Vulpia ciliata ssp. ambigua under natural conditions. Journal of Ecology, 81, 345 350 .

Yang, H., Jiang, L., Li, L., Li, A., Wu, M. \& Wan, S. (2012) Diversity-dependent stability under mowing and nutrient addition: evidence from a 7-year grassland experiment. Ecology Letters, 15, 619-626.

Zhen, L.N. (2012) Mechanism of arbuscular mycorrhizal fungi effect on the growth of adult plant and seedlings under clipping and N/P addition conditions. $\mathrm{PhD}$ Thesis, China Agricultural University, Beijing, China.

Zhou, H.S. (2013) Growth response of S. krylovii and A. frigida from steppe under different N/P supply. PhD Thesis, China Agricultural University, Beijing, China.

Received 1 November 2013; accepted 13 March 2014

Handling Editor: Marcel van der Heijden

\section{Supporting Information}

Additional Supporting Information may be found in the online version of this article:

Table S1. Plant species in the study sites.

Table S2. Results of ANOVA analyses for the biomass.

Table S3. Spearman's correlation coefficients between plant species.

Table S4. Results of ANOva analyses for the species richness.

Table S5. Results of ANOva analyses for $\mathrm{N}$ and $\mathrm{P}$ contents.

Figure S1. Soil available P and soil inorganic N.

Figure S2. Shoot $\mathrm{P}$ and $\mathrm{N}$ contents. 